\title{
Om å kjenne lusa på gangen
}

\author{
I Tidsskriftet nr. 23/1931 redegjør Alfred Sundal for nedgangen i luseplagen i osloskolen fra 1920. «Men hvorfor \\ er ikke utøiprocenten bragt ned til null?» spør han. Det er en sterk sosial gradient i «lusefrekvensen» i byen, \\ noe som lett lar seg avlese av skolenes «rangforordning». En midlertidig stigning i «utøyprosenten» følger \\ arbeidsløshetskurven, påviser han. Lus ble den gang sett på som et tegn på urenslighet. I dag kan kanskje for \\ høy grad av renslighet gi helseproblemer - men lusa er vi ikke kvitt... (Tidsskr Nor Lægeforen 1931; 51: \\ $1036-42)$.
}

\section{Pediculosis.}

Resultater av kampen mot utøi blandt skolebarn i Oslo. Av Alfred Sundal, Oslo.

Figuren gir et godt inntrykk av den store fremgang i renslighet fra 1920 til nu. Den viser hyppigheten av utøi blandt alle barn ved de to skolearter, særskole og folkeskole hver for sig. Vi ser, at blandt folkeskolebarnene er utøiprocenten sunket fra nesten 8 pct. i 1920 (24 768 elever) til litt over 1 pct. i 1930 (21 644 elever). Blandt særskolebarnene ligger utøiprocenten adskillig høiere som rimelig er; men også her har det vært et betydelig fall, nemlig fra 23 pct. i 1920 (541 elever) til 7 pct. i 1930 (636 elever). Vi legger merke til at fallet ikke er jevnt. I 1924 er der en stigning, og da materialet er meget stort, gjennemsnittlig ca. 23000 folkeskolebarn og ca. 600 særskolebarn, er sikkert denne stigning reel. Lusene er som bekjent meget stasjonære parasitter, og konservator $\mathrm{N}$ a t vig finner det høist usannsynlig at spesielle entomologiske eller klimatiske forhold kan spille nogen rolle. Årsaken må sikkert søkes i en dårligere renslighet og en slettere hygiene i det hele. Riktignok var høsten 1923 begynnelsen til en inflasjonsperiode som varte utover1924; men i samme grad som den norske krones kjøpekraft sank, steg lønningene (oplysninger fra Oslo statistiske kontor). Imidlertid viste arbeidsløsheten sig stigende, og det er vel rimelig at det er den større arbeidsløshet med dårligere økonomi, trangere boligforhold og lignende som bevirket stigningen i utøiprocenten.

Utøiprocenten er en meget god indikator på en bybefolknings hygiene. At utøiprocenten er avtatt, er et forhold som stemmer overens med en rekke andre observasjoner fra skolebarnsundersøkelser, som viser at det hygieniske nivå er steget. (Jvfr. den raskere legemsutvikling nu enn før.)

Ser vi på de enkelte skoler, finner vi - hvad vi på forhånd kunde vente - at de skoler hvis elever rekrutteres fra de socialt bedrestilte klasser, har den laveste utøiprocent. Høieste utøiprocent har de skoler som særlig har barn fra de socialt dårligst stillede strøk. Ser man igjennem hele serien av lister, finner man en temmelig ensartet rekkefølge fra år til år for de enkelte skoler.
Pediculosis. 1039

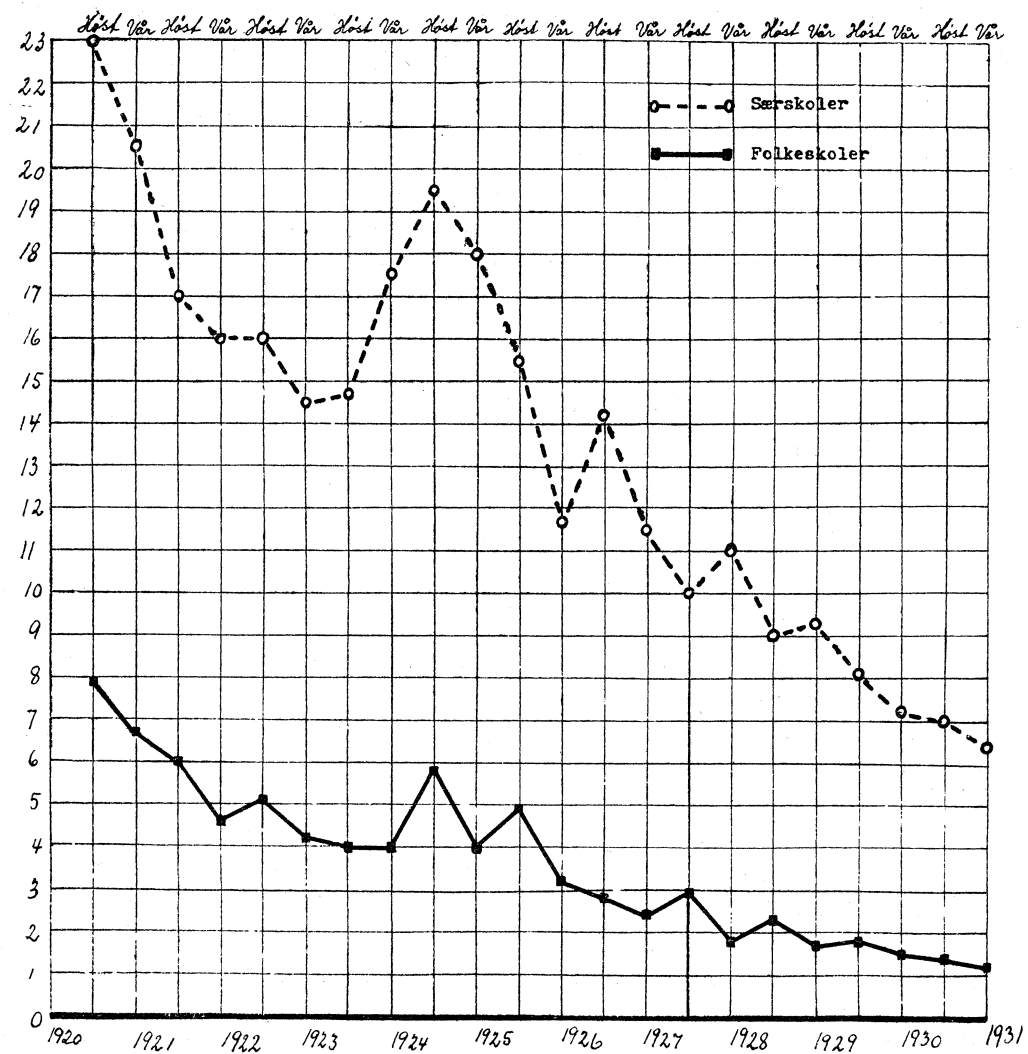

Fig. I. Procent barn med utøi. 